Original scientific article/Izvirni znanstveni članek

\title{
A comparison of frequency of medical interventions and birth outcomes between the midwife led unit and the obstetric unit in low-risk primiparous women Primerjava pojavnosti medicinskih intervencij in porodnih izidov pri nizkorizičnih prvorodnicah v samostojni babiški enoti in porodni enoti
}

\author{
Anita Prelec, Ivan Verdenik, Angela Poat
}

\author{
Key words: low risk; labour; \\ medical interventions; perinatal \\ outcomes \\ Ključne besede: nizko tveganje; \\ porod; medicinske intervencije; \\ perinatalni izidi \\ Anita Prelec, RN, MSc in \\ Midwifery (UK); University \\ Medical Centre Ljubljana, \\ Division of Gynaecology, \\ Department of Perinatology, \\ Šlajmerjeva 4, 1000 Ljubljana, \\ Slovenia \\ Correspondence e-mail/ \\ Kontaktni e-naslov: \\ anita.prelec@kclj.si \\ Ivan Verdenik, $\mathrm{PhD}$, University \\ Medical Centre Ljubljana, \\ Division of Gynaecology, \\ Research Unit, Šlajmerjeva 4, \\ 1000 Ljubljana, Slovenia \\ Angela Poat, RM, MEd, PhD \\ Lecturer, University of Hull, \\ Faculty of Health and Social \\ Care, Cottingham Road, Hull, \\ HU6 7RX, England, United \\ Kingdom
}

\section{ABSTRACT}

Introduction: The purpose of this national research was to compare birth, maternal and newborn outcomes in the midwife led unit and the obstetric unit to ascertain whether a midwife led unit reduced medicalisation of childbirth.

Methods: A prospective observational case-control study was carried out in Ljubljana Maternity Hospital in the period May - August 2013. The sample comprised 497 labouring women; 154 who attended the midwife led and 343 who attended in the obstetric unit, both matching the same inclusion criteria: low risk primiparous; singleton term pregnancies, normal foetal heart beat, cephalic presentation; spontaneous onset of labour. The primary outcome was the caesarean section rate. Chi-square test was used to compare medical interventions and birth outcomes.

Results: Women in the midwife led unit had statistically significant higher spontaneous vaginal births $(p<0.001)$, less augmentation with oxytocin $(p<0.001)$, less use of analgesia $(p<0.001)$, less operative vaginal deliveries $(p<0.001)$ and less caesarean sections $(\mathrm{p}<0.001)$, lower rates of episiotomy $(p<0.001)$ and more exclusively breastfed $(p=0.002)$.

Discussion and conclusion: These significant findings showed that in the midwife led unit fewer medical interventions were used. For generalisation of the findings more similar studies in Slovenia are needed.

\section{IZVLEČEK}

Uvod: Namen nacionalne raziskave je bila primerjava porodnih izidov ter izidov pri materah in novorojenčkih v samostojni babiški enoti in porodni enoti ter tako preveriti, ali so porodi $\mathrm{v}$ samostojni babiški enoti manj medikalizirani.

Metode: Prospektivna opazovalna raziskava primerov s kontrolami je bila izvedena med majem in avgustom 2013. V raziskavi je sodelovalo 497 žensk, 154 žensk je rodilo v samostojni babiški enoti in 343 žensk v porodni enoti. Obe skupini žensk sta izpolnjevali enak vstopni kriterij: prvorodnice brez prisotnih dejavnikov tveganja, ob porodnem terminu, z enim plodom v glavični vstavi, normalno plodovo frekvenco srca in spontanim začetkom poroda. Primarni izid je bil delež carskih rezov. Za primerjavo medicinskih intervencij in porodnih izidov v obeh skupinah je bil uporabljen test hi-kvadrat.

Rezultati: Ženske, ki so rodile v samostojni babiški enoti, so imele statistično pomembno več spontanih vaginalnih porodov $(p<0.001)$, manj pospeševanj z oksitocinom $(p<0.001)$, manjšo uporabo analgetikov $(p<0.001)$, manj operativnih vaginalnih porodov $(p<0.001)$ in carskih rezov $(p<0.001)$, manj epiziotomij $(p<0.001)$ in več polnega dojenja $(p=0.002)$.

Diskusija in zaključek: $\mathrm{V}$ samostojni babiški enoti je bilo uporabljenih manj medicinskih intervencij. Za generalizacijo zaključkov te študije bi bile potrebne nadaljne raziskave v Sloveniji.

The article is based on the MSc thesis of Anita Prelec:

A comparison study between the birth processes, maternal and newborn outcomes in the midwife led birthing unit and an ordinary labour ward in the Ljubljana Maternity Hospital (2013). 


\section{Introduction}

Pregnancy and childbirth are crucial life events for every woman. A normal physiological labour and birth is powered by the innate human capacity of the woman and fetus. Supporting the normal physiologic processes of labour and birth has the potential to enhance best outcomes for the mother and newborn (American College of Nurse-Midwives, 2013).

The increase of medicalisation of childbearing and women's dissatisfaction with maternity services have been publicly uttered worldwide (National Institute for Health and Clinical Excellence, 2007). Different models of care for childbearing women were introduced: home births, the development of midwifeled services and the development of birth centres, either inside or outside the hospital (Guilliland, et al., 2006). However, too many healthy pregnant women still have medicalized birth in obstetric settings. Many women have had physical and mental trauma as a result of unnecessary medical interventions, affecting their birth experiences (Parry, 2008). These types of experiences were not recognized as biological and individualistic (Inhorn, 2006). However, Christiaens (2011) claimed that the use of medical technology makes childbirth relatively predictable and controllable and therefore a preferred option for some women and health professionals.

In many parts of the world midwives are primary care givers in childbearing (Page, 2007). In Slovenia (Zakon o zdravniški službi, 2006) and other parts of the world (Government of Western Australia, 2003) care is shared or exclusively performed by physicians or gynaecologists. According to the National Institute for Health and Clinical Excellence (2007) guidelines and the International Confederation of Midwives (ICM) (2008a) statements, midwives as the primary caregivers are the safest and the most cost effective experts in normal childbirth.

International Confederation of Midwives (2008b) argues that all women should have access to midwifery-led care. There are different models of midwifery led services for low risk women: midwifery team (McCourt, 2006) and caseload midwifery, with greater continuity of caregiver throughout the ante, intra and postpartum care (Johnson, et al., 2003; McLachlan, et al., 2012). These models show significant improvements in maternal outcomes when compared to standard care and address women's specific needs, preferences and expectations (Hatem, et al., 2008) and satisfaction with antenatal care (Wiysonge, 2009).

Kitzinger (2011) argued that midwife led units (MLU) are the soft transition from medicalised care to women friendly, but still hospitalised care for women in labour. The evidence shows that women who give birth in a MLU are more likely to have a normal birth in comparison to women who plan to give birth in an obstetric unit (OU) (National Institute for Health and
Clinical Excellence, 2007). The measured outcomes in MLU fortify changes in maternity service: high-quality and safety (Wiegers, 2009), less medical interventions (Overgaard, et al., 2011; Suzuki, et al., 2011), reduced caesarean section and instrumental vaginal births (Janssen, et al., 2007), less use of analgesia and episiotomy (Eide, et al., 2009), control during labour, more spontaneous vaginal births and initiating of breastfeeding (Hatem, et al., 2008). Sutcliffe (2012) described midwifery led care as effective, cost-effective, and efficient health care not just to women, but also to their families and communities.

Introduction of different models of care in Slovenian maternity service has taken too long despite the needs and strong ambitions of women and midwives efforts. The first alongside MLU was established in the Postojna Maternity Hospital in 2011. Women have good access to public maternity services; however, they meet various caregivers during the childbirth continuum and studies have shown that multiple prenatal care providers give different information to women, which results in confusion and anxiety (Metcalfe, et al., 2013).

Hadjigeorgiou and colleagues (2012) stated that many women's choices about the place of birth are medically oriented. Their statement was based on critical synthesis of 23 published researches concerning women's experiences in choosing where to give birth. Contrary, Jomeen and Martin (2008) claimed that in reality - birth place choices are just an illusion. Nevertheless, the researcher believes that each woman has the right to choose the birth place in Slovenia, however, in current maternal service these options are limited.

\section{Aimes and objectives}

With the introduction of MLUs in Ljubljana Maternity Hospital there was a unique opportunity to examine how MLU effects maternal and newborns outcomes. The aim of this research was to compare the birth processes, maternal and newborn outcomes of labours managed in the MLU to those managed in the OU for low risk primiparous women. The research hypothesis stated that negative secondary outcomes in MLU would be lowered by $15 \%$.

\section{Methods}

The research was based on a quantitative research method. A prospective observational case-control design was chosen. As Mann (2003) stated, case-control studies are mostly retrospective, however, they could be an acceptable method for studying numerous problems, particularly where randomised control research would be unethical, inappropriate or inadequate. Therefore a case-control study was chosen as the most appropriate design. To avoid unethical issues, respect the women's autonomy and 
rights to choose a place of birth, the choice for prospective observational case-control study was a reasonable decision. The data were collected using a partogram and a database of the National Perinatal Information System.

The study was conducted between May and August 2013.

\section{Description of the research instrument}

The primary outcome of the research was the caesarean section rate because in a MLU the rate of caesarean section rate should be lower. Among the secondary outcomes of the research the birth outcomes and medical interventions, such as spontaneous rupture of membranes, electronic fetal monitoring, augmentation with oxytocin, use of analgesia and operative vaginal delivery were analysed. Among the maternal outcomes spontaneous vaginal birth, rate of episiotomy, perineal laceration, postpartum hemorrhage of more than $500 \mathrm{ml}$, transfusion and manual removal of placenta were evaluated. Newborn's characteristics, such as gender, resuscitation, referral to Neonatal Intensive Care Unit, Apgar score less than 6, breastfeeding and birth weight were also considered.

In this research, the intervention was defined as the labour of low risk women managed by midwives in the MLU, using the clinical pathway for normal birth introduced as a new standard for low risk women in labour which started in the beginning of 2012. The control was defined as the labour of low risk women giving birth in the OU.

\section{Description of the sample}

Preliminary data from the National Perinatal Information System in 2012 indicated that the incidence of the negative secondary outcomes such as episiotomy, third and fourth degree perineal tears, postpartum haemorrhage and transfusion among controls was $40 \%$. In this case the sample needed for the study (considering 1: 2 ratio of cases versus controls) was 155 case subjects and 309 control subjects to be able to reject the hypothesis that the failure rates for experimental and control subjects were equal with probability (power) 0.8 .

During the research, there were 1916 labouring women in Ljubljana Maternity Hospital, 1843 pregnant women with a singleton. 910 women gave births for the first time, 600 of them were at term. 20 newborns were born in breech position. For the purpose of this research, an additional 83 women were excluded for referral to tertiary centre, gestational diabetes, fetal growth restriction, mental and other health disorders. The final group of 497 healthy primiparous pregnancies was included in this research. The inclusion criteria for participants were: low risk primiparous women; singleton pregnancies at $37^{+0}-41^{+3}$ weeks of gestation; normal foetal heart beat according to NICE guidelines (National Institute for Health and Clinical Excellence, 2007); cephalic presentation; spontaneous onset of labour; active phase of labour (at least 3 contractions in 10 minutes and cervix dilated to at least $3 \mathrm{~cm}$ according to the policy of the Ljubljana Maternity Hospital). 154 women decided to give birth in MLU (signed as a study group) and 343 women were located in OU (control group). The MLU is managed by midwives who promote physiological childbirth to minimize interventions during the labour. The group of low risk women fulfilling the inclusion criteria for MLU and expressing natural, non medicalised birth were defined as the study group. This approach to defining a case was also suggested by Yin (2003) who said that cases for case study can be projects, programmes, persons or groups of persons.

Table 1: Demographic data

Tabela 1: Demografski podatki

\begin{tabular}{|c|c|c|c|c|c|}
\hline \multirow[t]{2}{*}{$\begin{array}{l}\text { Items/ } \\
\text { Postavke }\end{array}$} & \multicolumn{2}{|c|}{$\begin{array}{c}\text { Study group/ } \\
\text { Eksperimentalna skupina }\end{array}$} & \multicolumn{2}{|c|}{$\begin{array}{c}\text { Control group/ } \\
\text { Kontrolna skupina }\end{array}$} & \multirow[t]{2}{*}{$p^{*}$} \\
\hline & $n=154$ & $\%$ & $n=343$ & $\%$ & \\
\hline Marital status & & & & & $0.894^{*}$ \\
\hline Single & 4 & 2.6 & 11 & 3.2 & \\
\hline Married & 66 & 42.9 & 152 & 44.3 & \\
\hline Cohabitation & 84 & 54.5 & 179 & 52.2 & \\
\hline Widow & - & - & 1 & 0.3 & \\
\hline $\begin{array}{l}\text { Education less than higher } \\
\text { degree }\end{array}$ & 70 & 45.5 & 161 & 46.8 & $0.846^{*}$ \\
\hline Presence of a companion & 141 & 91.6 & 314 & 91.5 & $0.749^{*}$ \\
\hline Prenatal classes & 143 & 92.9 & 307 & 89.5 & $0.238^{*}$ \\
\hline Age $(\bar{x})$ & & & & & $\begin{array}{c}0.687^{\star} \\
0.864(\mathrm{MWt})^{\star *}\end{array}$ \\
\hline
\end{tabular}

Legend/Legenda: $n$ - number/število; \% - percentage/odstotek; $p^{*}$ - Chi-square test, a statistically significant value in the 0.05 or less/ test hi-kvadrat, statistično pomembna vrednost pri 0,05 ali manj; $M W t^{* *}$ - Mann-Whitney test/Mann-Whitneyev test; $\overline{\mathrm{x}}$ average/povprečje 
By testing and comparing case and control groups the objective was to determine whether or not there were substantial differences in a process as described by Mann, (2003). To make sure that both groups are homogenous, several measures were taken. In the study period the inclusion criteria were reviewed by the midwives during the admission processes of primiparous pregnancies at Ljubljana Maternity Hospital and once again in the labour ward. All the women not meeting the inclusion criteria were not enrolled in the study.

Table 1 shows the demographic data for both groups of included women. In the study group the average age was 28.51 versus 28.67 years $(p=0.687)$ in the control group. 70 (45.5\%) women in the study group have less than higher degree education, while in the control group the number of women is 161 (46.8 $\%)(p=0.784)$. In the study group $4(2.6 \%)$ women were single, 66 (42.9\%) were married and 84 (54.5 $\%)$ women were cohabitating. In the control group 11 (3.2\%) women were single, $152(44.3 \%)$ women were married, $179(52.2 \%)$ were cohabitating and $1(0.3 \%)$ woman was declared as a widow.

141 (91.6\%) women in the study group and 314 (91.5 $\%)$ in the control group had a companion of her choice during the labour. 143 (92.9 \%) women in the study group and $307(89.5 \%)$ women in the control group have attended prenatal classes. According to the data from the National Perinatal Information System both groups of women were representative of the population of primiparous women, which gave birth in Slovenia in 2012. No statistical differences were detected between the demographic data of the groups.

\section{Description of the research procedure and data analysis}

The research involved human participants and increased the question of ethical proprietary. Every aspect of this research was guided by national and international ethical research standards, including the right to privacy, confidentiality, anonymity, voluntary participation and the right to withdraw (Pravilnik o sestavi, nalogah, pristojnostih in načinu dela komisije za medicinsko etiko, 1995; World Medical Association, 2000; Directive 2001/20/EC, 2001).

A letter requesting access to the databases was addressed to the management of the University Medical Centre, Department of Obstetrics \& Gynaecology, Head of Ljubljana Maternity Hospital and Head Midwife of Ljubljana Maternity Hospital. On obtaining access permission the researcher received approval from the National Medical Ethics Committee of the Republic of Slovenia ( $\mathrm{N}^{0} 89 / 01 / 12$ ), Ethics Committee of the University Medical Centre Ljubljana and the Ethics Committee of the School of Health and Life Sciences at Glasgow Caledonian University. During the research, the necessary steps were taken to ensure that the integrity of participants was recognized and protected. The main ethical issues to be addressed during the study pertained to consent and confidentiality. The study started on 1st of May 2013 and finished on 15 of August 2013.

The information sheet was presented by the researcher to the pregnant women and their partners at three main (introductory) lessons at prenatal classes organized by the Ljubljana Maternity Hospital. Informed and voluntary consent was an explicit agreement by the participants, which was given without inducement or threat. More than 500 participants, who were interested, received the information sheet. Potential participants also received information during individual consultation with the midwives at Ljubljana Maternity Hospital, after 36 week of gestation and before the admission to the labour ward. Participants were asked to sign a informed consent form which reflected their voluntary participation in the research and it became part of their medical files. When women in labour came to MLU or OU, the midwives in admission room checked the inclusion criteria once again and confirmed their participation in the research. It was clearly expressed in the written and verbal details that no reason or explanation was required if participants chose to withdraw from the study.

From the beginning until the end of the research, special attention to protect the anonymity and confidentiality of the participants was undertaken. To protect anonymity of the participant's numbering/ coding was used throughout the research process. Assurances were given to participants that any information gained during the research would be held in the strictest confidence. All the papers were kept in a locked office with restricted access. In addition, password protected computer and disposal of data by the researcher and the anonymity of participants in any reports or publications generated as a result of this research were guaranteed. Safeguarding of medical records during and after the research process were carried out in accordance with Slovenian data protection regulation.

Due to stringent inclusion and exclusion criteria the sample obtained were homogeneous groups. Therefore univariate analysis was sufficient. Results were presented using numbers and percentages for categories, with means and standard deviation for continuous variables. For comparison of categorical outcomes between groups the chi-square test was used, while for continuous variables Student t-test or MannWhitney test were used (dependent on distributional normality). Statistical analysis was performed using SPSS ver. 21 . Differences were considered statistically significant when $p<0.05$.

The Type I error probability associated with the testing of the hypothesis was 0.05 . For the calculation of required sample size, EPI Info StatCalc programme has been used. 


\section{Results}

Some of the key findings are presented below.

\section{Birth outcomes and medical interventions}

Some medical interventions during the labour and birth outcomes are presented in Table 2 .
Spontaneous rupture of membranes occurred in $69(44.8 \%)$ women in the study group and 168 (49 $\%)$ women in the control group. Electronic fetal monitoring was used in $153(99.4 \%)$ labours in the study group and in 339 (98.5\%) labours in the control group. No augmentation with oxytocin was necessary in $106(68.8 \%)$ labours in the study group and 55 (16.0 $\%)(p<0.001)$ labours in the control group, which was

Table 2: Birth outcomes and medical interventions

Tabela 2: Porodni izidi in medicinske intervencije

\begin{tabular}{|c|c|c|c|c|c|}
\hline \multirow[t]{2}{*}{$\begin{array}{l}\text { Items/ } \\
\text { Postavke }\end{array}$} & \multicolumn{2}{|c|}{$\begin{array}{c}\text { Study group/ } \\
\text { Eksperimentalna skupina }\end{array}$} & \multicolumn{2}{|c|}{$\begin{array}{c}\text { Control group/ } \\
\text { Kontrolna skupina }\end{array}$} & \multirow[t]{2}{*}{$p^{*}$} \\
\hline & $n=154$ & $\%$ & $n=343$ & $\%$ & \\
\hline $\begin{array}{l}\text { Spontaneous rupture of } \\
\text { membrane }\end{array}$ & 69 & 44.8 & 168 & 49.0 & $0.491^{\star}$ \\
\hline $\begin{array}{l}\text { Electronic fetal } \\
\text { monitoring }\end{array}$ & 153 & 99.4 & 339 & 98.5 & \\
\hline Augmentation (oxytocin) & & & & & $<0.001^{*}$ \\
\hline 1st stage of labour & 33 & 21.4 & 257 & 74.9 & \\
\hline 2nd stage of labour & 15 & 9.7 & 31 & 9.0 & \\
\hline No augmentation & 106 & 68.8 & 55 & 16.0 & \\
\hline Analgesia & & & & & $<0.001^{*}$ \\
\hline Pharmacological & 90 & 58.4 & 273 & 79.6 & \\
\hline Nitrous oxide & 52 & 33.8 & 64 & 18.7 & \\
\hline Not used & 12 & 7.8 & 6 & 1.7 & \\
\hline $\begin{array}{l}\text { Operative vaginal delivery } \\
\text { (vacuum) }\end{array}$ & 1 & 0.6 & 16 & 4.7 & $<0.001^{\star}$ \\
\hline Ceasarean section & 3 & 1.9 & 46 & 13.4 & $<0.001^{\star}$ \\
\hline
\end{tabular}

Legend/Legenda: $n$ - number/stevilo; \% - percentage/odstotek; $p^{*}$ - Chi-square test, a statistically significant value in the 0.05 or less/ test hi-kvadrat, statistično pomembna vrednost pri 0,05 ali manj

Table 3: Maternal outcomes

Tabela 3: Maternalni rezultati

\begin{tabular}{|c|c|c|c|c|c|}
\hline \multirow[t]{2}{*}{$\begin{array}{l}\text { Items/ } \\
\text { Postavke }\end{array}$} & \multicolumn{2}{|c|}{$\begin{array}{c}\text { Study group/ } \\
\text { Eksperimentalna skupina }\end{array}$} & \multicolumn{2}{|c|}{$\begin{array}{l}\text { Control group/ } \\
\text { Kontrolna skupina }\end{array}$} & \multirow[t]{2}{*}{$p^{*}$} \\
\hline & $n=154$ & $\%$ & $n=343$ & $\%$ & \\
\hline $\begin{array}{l}\text { Spontaneous vaginal } \\
\text { labour (without ceasarean } \\
\text { section, vacuum, perineal } \\
\text { laceration and episiotomy) }\end{array}$ & 100 & 64.9 & 142 & 41.4 & $<0.001^{\star}$ \\
\hline $\begin{array}{l}\text { Episiotomy (vaginal } \\
\text { delivery) }\end{array}$ & 51 & 33.8 & 155 & 52.2 & $0.001^{\star}$ \\
\hline Laceration & & & & & $0.063^{*}$ \\
\hline 1st and 2 nd degree & 18 & 11.7 & 61 & 17.8 & \\
\hline 3 rd and 4 th degree & 1 & 0.6 & 5 & 1.5 & \\
\hline $\begin{array}{l}\text { Postpartum haemorrhage } \\
>500 \mathrm{ml} \text { - atonia }\end{array}$ & 2 & 1.3 & 19 & 5.5 & $0.085^{\star}$ \\
\hline Transfusion & - & - & 2 & 0.6 & \\
\hline $\begin{array}{l}\text { Manual removal of } \\
\text { placenta and extraction of } \\
\text { tissue }\end{array}$ & 5 & 3.2 & 25 & 7.3 & $0.216^{*}$ \\
\hline
\end{tabular}

Legend/Legenda: $n$ - number/število; \% - percentage/odstotek; $p^{*}$ - Chi-square test, a statistically significant value in the 0.05 or less/ test hi-kvadrat, statistično pomembna vrednost pri 0,05 ali manj 
a significant difference. In the first stage of labour the augmentation with oxytocin was used in $257(74.9$ $\%)$ labours in the control group and $33(21.4 \%)(p<$ 0.001 ) labours in the study group. Less than $10 \%$ of labours in both groups were augmented with oxytocin in the second stage of labour. $90(58.4 \%)$ women in the study group and $273(79.6 \%)(p<0.001)$ in the control group used pharmacological analgesia, such as pethedine and remifentanyl during the labour. Nitrous oxide was used by $52(33.8 \%)$ women in the study group and by $64(18.7 \%)$ women in the control group. No analgesia in labour was seen in $12(7.8 \%)$ women in the study group and in $6(1.7 \%)(p<0.001)$ women in the control group.

Vacuum extraction was used for 1 birth $(0.6 \%)$ in the study group and $16(4.7 \%)(p<0.001)$ births in the control group, demonstrating a significant difference. Caesarean section was required for $3(1.9 \%)$ women in the study group and $46(13.4 \%)(p<0.001)$ women in the control group, which also demonstrated a significant difference.

\section{Maternal outcomes}

Maternal outcomes in both groups of women are presented in Table 3.

Table 3 shows there was spontaneous labour (without ceasarean section, operative delivery, perineal laceration and episiotomy) for 100 (64.9\%) women in the study group and $142(41.4 \%)(p<0.001)$ women in the control group showing a significant difference in this perinatal outcome. Episiotomy occurred in $51(33.8 \%)$ women in the study group and in $155(52.2 \%)(p=0.001)$ women in the control group again showing a significant difference in this characteristic. In the study group, $18(11.7 \%)$ women had perineal laceration of first and second degree and $1(0.6 \%)$ woman had third and fourth degree perineal laceration, while in the control group this ratio was 61 (17.8 \%) (first and second degree) and 5 (1.5\%) (third and fourth degree), which did not show any statistical difference. Postpartum haemorrhage with severe bleeding of more than $500 \mathrm{ml}$ of blood was presented in $2(1.3 \%)$ births in the study group and in $19(5.5 \%)(p$ $=0.085)$ births in the control group indicating there was no significant difference in postpartum haemorrhage. Blood transfusions were needed for 2 women, who gave birth in the control group and none in the study group. Oxytocin was used for the active management of the third phase of labour in both groups. Manual removal of retained placenta and extraction of placental tissue was conducted in $5(3.2 \%)$ cases in the study group and $25(7.3 \%)(p=0.216)$ cases in the control group with no significant differences noted.

\section{Newborn outcomes}

Table 4 shows the newborn's characteristics and some of their outcomes.

In the study group, there were $82(53.2 \%)$ males and $176(51.3 \%)(p=0.690)$ males in the control group. In the control group, $1(0.3 \%)$ newborn needed aspiration and $4(1.2 \%)(p=0.322)$ newborns ventilation. There was no need for any of the resuscitation measures in the study group. $2(1.3 \%)$ newborns from the study group and 3 newborns $(0.9 \%)(p=0.780)$ from the control group were referred to Neonatal Intensive Care Unit.

Table 4: Newborn outcomes

Tabela 4: Izidi novorojenčkov

\begin{tabular}{|c|c|c|c|c|c|}
\hline \multirow[t]{2}{*}{$\begin{array}{l}\text { Characteristics/ } \\
\text { Postavke }\end{array}$} & \multicolumn{2}{|c|}{$\begin{array}{c}\text { Study group/ } \\
\text { Eksperimentalna skupina }\end{array}$} & \multicolumn{2}{|c|}{$\begin{array}{c}\text { Control group/ } \\
\text { Kontrolna skupina }\end{array}$} & \multirow[t]{2}{*}{$p^{*}$} \\
\hline & $n=154$ & $\%$ & $n=343$ & $\%$ & \\
\hline Male gender & 82 & 53.2 & 176 & 51.3 & $0.690^{*}$ \\
\hline Resuscitation measures & & & & & $0.322^{*}$ \\
\hline Aspiration & - & - & 1 & 0.3 & \\
\hline Ventilation & - & - & 4 & 1.2 & \\
\hline None & 154 & 100 & 338 & 98.5 & \\
\hline $\begin{array}{l}\text { Referral to Neonatal } \\
\text { Intensive Care Unit }\end{array}$ & 2 & 1.3 & 3 & 0.9 & $0.780^{*}$ \\
\hline Breastfeeding & & & & & $0.002^{*}$ \\
\hline Only & 124 & 80.5 & 237 & 69.1 & \\
\hline Partial & 28 & 18.2 & 86 & 25.1 & \\
\hline No & 2 & 1.3 & 20 & 5.8 & \\
\hline \multicolumn{6}{|l|}{ Apgar score less than 6} \\
\hline 1 minute & 1 & 0.6 & 7 & 2.0 & $0.254^{*}$ \\
\hline 5 minute & - & - & 4 & 1.2 & $0.178^{*}$ \\
\hline Birth weight $(\overline{\mathrm{x}})$ & \multicolumn{2}{|c|}{3362 grams } & \multicolumn{2}{|c|}{3422 grams } & $0.136^{*}$ \\
\hline
\end{tabular}

Legend/Legenda: $n$ - number/število; \% - percentage/odstotek; $p^{*}$ - Chi-square test, a statistically significant value in the 0.05 or less/ test hi-kvadrat, statistično pomembna vrednost pri 0,05 ali manj; $\overline{\mathrm{x}}-$ mean/povprečje 
$124(80.5 \%)$ newborns in the study group and 237 $(69.1 \%)(p=0.002)$ newborns in the control group were fully breastfed at the discharge, which showed no significant difference. Partially breastfed newborns were $28(18.2 \%)$ in the study group and $86(25.1 \%)$ newborns in the control group, while 22 newborns were not breastfed at all, $2(1.3 \%)$ of them being in the study group and 20 (5.8\%) in the control group.

Apgar scores of less than 6 at one minute was recorded for $1(0.6 \%)$ newborn in the study group and $7(2 \%)$ newborns in the control group; and at five minutes there were $4(1.2 \%)$ newborns in the control group and none in the study group. No statistical differences were found.

The average birth weight of the newborns was 3362 grams in the study group, while newborns average birth weight in the control group was 3422 grams $(p=0.136)$ and there was no statistical difference observed.

In conclusion, the researcher hypothesised that negative secondary outcomes such as episiotomy, third and fourth degree perineal tears, postpartum haemorrhage and transfusion will be lowered by $15 \%$ in the MLU. The results show that all negative secondary outcomes in the OU were $59.8 \%$ compared to $35.7 \%$ in the MLU. The difference in negative secondary outcomes was $24.1 \%$.

\section{Discussion}

The researcher cannot exclude the possibility that the low rate of medical interventions in the MLU is associated with the motivation of pregnant woman who choose birth in such a unit, with a greater possibility to have natural birth. High motivation for non interventions was advocated by midwives and employees in such units. This awareness of possible bias was also expressed by many authors of comparison studies (Eide, et al., 2009; Berg, et al., 2012; Ryan, et al., 2013). On the contrary, Johanson and colleagues (2002) expressed the view that the medicalised philosophy and thinking in many OUs, is why many medical interventions become routine, and used for "just in case «, such as artificial rupture of membranes, fetal monitoring and routine intravenous cannulation, despite the strong public awareness about unnecessary medical interventions need to be decreased.

Procedures, such as electronic fetal monitoring were used in almost all births in both units despite clinical recommendations. The recommendations of Ljubljana Maternity Hospital and NICE guidelines (2007) stated that continuous fetal monitoring is not necessary in first stage of labour in healthy pregnancies. For healthy, low risk women, intermittent auscultation of the fetal heart beat has been recommended.

There were more reasons why some procedures in the MLU are still medicalized. Due to organisational and financial problems in the last years, independent
MLU in Ljubljana Maternity Hospital was not fully realised. During the implementation of this study, the MLU and the OU were not completely separate entities; therefore the OU policies still influenced practice in the MLU. This was also shown in other outcomes, such as artificial rupture of membranes, augmentation, use of pharmacological analgesia.

The significant differences in augmentation of labour showed the medical nature of this intervention was higher in the OU. Suzuki and colleagues (2011) in their study of primiparous women shows that using oxytocin is $10 \%$ in the MLU versus $38 \%$ in the OU. It is however hard to compare the findings from different studies because of different study designs and participants included in the studies.

The findings about the use of analgesics in this research showed significant difference between the two groups, whereas Symon and colleagues (2011) in their comparison study of primiparous showed a much lower rate of $25 \%$ in the MLU versus $77 \%$ in the OU. In the same study, the use of no pharmacological methods were presented, $72 \%$ in the MLU versus 21 $\%$ in the OU. This is in agreement with the findings of the present study which found the use of nitrous oxide as a non pharmacological method was more likely in the MLU.

The significant differences shown in selected medical interventions and birth outcomes, such as vaginal operative delivery and caesarean section rate were supported by other research. In Suzuki and colleagues (2011) the comparison study showed that $5.9 \%$ deliveries were assisted (vacuum, forceps) in the MLU versus $7.8 \%$ in the OU. Overall, the caesarean section rate was higher in the OU than in the MLU and these data were comparable to other equivalent studies (Janssen, et al., 2007; Eide, et al., 2009; Symon, et al., 2011).

In this research the rate of episiotomy in the MLU was significantly lower than in the OU. These variations in episiotomy rate may explain the possibility of different positions during birth, such a walking, kneeling or telemetric fetal monitoring. Certainly the high occurrence of episiotomy in both groups is an issue of concern. Most midwives in Slovenia are convinced that it is better to perform the episiotomy to prevent severe injures of birth canal and this could be a reason of high episiotomy rate in the OU and the MLU. Eide and colleagues (2009) compared interventions in two different units and produced findings similar to those in the current research.

Severe injuries of the birth canal and postpartum haemorrhage were rare events, however, one of the most important health quality indicators. Findings similar to this study were reported in other studies (Janssen, et al., 2007; Suzuki, et al., 2011). However, the finding in relation to the outcome postpartum haemorrhage was hard to evaluate, because of different criteria for blood loss volume (from $500 \mathrm{ml}$ 
to $1000 \mathrm{ml}$ ). Suzuki and colleagues (2011) reported postpartum haemorrhage of more than $1000 \mathrm{ml}$ in $2.6 \%$ labours in the MLU versus $4.4 \%$ labours in the OU, while Janssen and colleagues (2007) reported the incidence of severe haemorrhage in more than $5 \%$ of births in both group (5.5\% in the MLU versus $5.1 \%$ in the $\mathrm{OU})$.

Manual removal of placenta was a rare obstetric intervention in maternity units and not of interest to many researchers. However, Janssen and colleagues (2007) reported $1.4 \%$ cases in the MLU versus $1.7 \%$ in the OU, and these findings a similar to the current study.

The neonatal findings show that resuscitation measures were not often used in birth units for low risk pregnancies; Apgar score at first and fifth minute or $\mathrm{pH}$ of umbilical cord were thought to be more valuable measures (Suzuki, et al. 2011). In Janssen and colleagues (2007) the study shows that admission to neonatal intensive care unit was less likely in the MLU. The reason for all five referrals to Neonatal Intensive Care Unit in the MLU and the OU were transient neonatal tachypnea. It seems that newborn birth weight for primiparous labours shows discrepancy worldwide. Newborns born in Japan had average birth weight of 3019 grams in the MLU and 2956 grams in the OU, while in Canada average newborn's weight was 3609 grams in the MLU and 3476 grams in the OU. In current research, no significant difference was noted in newborns birth weight in the MLU and the OU. However, this variable and differences in birth weight worldwide could be an interesting future research study.

The findings from current research showed significant differences in fully breastfeeding rate at discharge; women in the MLU were more likely to fully breastfeed than women in control group. The evidence has shown a correlation between the use of oxytocin during the labour and breastfeeding and many authors expressed a great variety of possible side effects (Odent, 2013). Odent (2013) also claimed that the increasing incidence of breastfeeding difficulties and earlier cessation of breastfeeding are directly related to the use of oxytocin during the labour. The significantly higher use of oxytocin in control group in current research could corroborate this evidence.

\section{Limitations}

There are several limitations that need to be acknowledged and addressed regarding this study.

Research based on case-control studies has some weaknesses. This type of study often requires a large number of participants, and can suffer from the limitations of selection bias such as sampling, observation or recall bias among participants and confounding variables. To avoid selection bias in this research, inclusion criteria for participants were straightforward and double checked (at admission and in the labour room).

The research included only the physical components of the labour, but not other very important factors such as satisfaction of women, impact of accompaning person, parental self-esteem.

The researcher is the head midwife of the labour ward in Ljubljana Maternity Hospital and this fact could be a potential bias. She was involved in the implementation of the MLU in Ljubljana Maternity Hospital and positive outcomes of this study will have significant impact on the future of the MLU. However, the study was running 24 hours per day and the all midwifery team (more than 50 midwives) were included in the research.

The midwives involved in the study expressed concerns that instructions (for example including criteria, personal history) were not clear enough or they did not fully take them into account. This was the reason to exclude 83 women from the research.

Due to organisational and financial problems in the last years, independent MLU in Ljubljana Maternity Hospital was not fully realised. During the implementation of this study, the MLU and the OU were not completely separate entities; therefore OU policies still influenced practice in MLU.

This study was also limited by the fact that pregnant women were not randomly allocated to the MLU or the OU. During the process of formulation of the study design, the researcher decided that women's choice of place of birth would be the priority. Therefore some precautions must be adopted in any attempt to generalise these findings because of the non-randomised design. A study covering a longer period, including several MLU and OU in Slovenia and a larger sample would have a greater impact on generalisabilty of the findings.

\section{Conclusion}

In conclusion, some recommendations based on research findings in relation to clinical practice, further research and maternity policy are highlighted.

In clinical practice, the construction and implementation of the protocols and the guidelines for midwifery practice could be framed. To avoid unnecessary medical interventions, these protocols and guidelines should be based on appropriate scientific evidence. Midwives, who do not use evidenced based midwifery practice, also limit women's choice.

In the future, a randomised controlled research examining both units, the MLU and the OU, would permit a conclusive review of the birth, maternal and newborns outcomes. Such study design reduces bias, which was identified in the present research. With a larger sample of participants the generalisations of the findings to the Slovenian population would be possible. 
Additionally, there is an evident lack of research designed especially in the context of Slovenian pregnant women's needs and the perception of the new model of midwifery led care. Therefore research should be conducted to explore their needs and perceptions.

In the field of maternity policy, establishment of standards for independent midwife led unit in Ljubljana Maternity Hospital is crucial. Such document would include standards for organisation, administration, facility, equipment, staff and personnel, evaluation of quality of care and service as well as standards for midwifery research. The new standards for independent midwifery led unit should bring different view on daily practice - more women centred care, supported by midwifery philosophy. Therefore, standards for the MLU should be written, based on evidence based midwifery and midwifery competences.

The changes that influenced the nature and the scope of midwifery practice and midwives competences in the MLU had some benefits for women's health. However, it is noticeable from the evidence of the current study that medicalisation in both study units still persists. Midwives and obstetricians provide different services during the labour to women and obstetricians usually use medical interventions more frequently, such as operative delivery and induction of labour. Generally, the medicalisation of childbirth in Ljubljana Maternity Hospital was evident predominantly in hospital births, artificial rupturing of membranes, augmentation with oxytocin in labour, continuous fetal monitoring, less use of none pharmacological methods of pain reliever, high rate of episiotomy and operative delivery.

In conclusion, the evidence of this national research indicated that women who received care in the MLU encountered a range of physical benefits, such as more spontaneous labour, less augmentation with oxytocin, less pharmacological use of pain relief, less vaginal operative deliveries and caesarean sections. More newborns born in the MLU were fully breastfed. These results should encourage other maternity clinics in Slovenia to step forward and start to make changes in the current maternity service, set up the MLUs and evaluate their own findings.

\section{Literature}

American College of Nurse-Midwives, 2013. Supporting healthy and normal physiological childbirth: a consensus statement by ACNM, MANA and NACPM. Journal of Perinatal Education, 22(1), pp. 14-17.

PMid:24381472; PMCid:PMC3647729

Berg, M., Asta Ólafsdóttir, O. \& Lundgren, I., 2012. A midwifery model of woman - centred childbirth care - in Swedish and Icelandic settings. Sexual and Reproductive Healthcare, 3(2), pp. 79-87.

http://dx.doi.org/10.1016/j.srhc.2012.03.001

PMid:22578755
Christiaens, V., 2011. Pregnant women's fear of childbirth in midwife - and obstetrician-led care in Belgium and the Netherlands: test of the medicalization hypothesis. Womens Health, 51(3), pp. 220-239.

http://dx.doi.org/10.1080/03630242.2011.560999

PMid:21547859

Directive 2001/20/EC on the approximation of the laws, regulations and administrative provisions of the Member States relating to the implementation of good clinical practice in the conduct of clinical trials on medicinal products for human use., 2001. Luxembourg: European Parliament and of the Coucil, 2001. Available at: http://www.eortc.be/services/doc/clinical-eudirective-04-april-01.pdf [15. 6. 2014].

Eide, B.I., Nilsen, A.B.V. \& Rasmussen, S., 2009. Births in two different delivery units in the same clinic - a prospective study of healthy primiparous women. BioMed Central Pregnancy and Childbirth, 25(9), pp. 3-12.

http://dx.doi.org/10.1186/1471-2393-9-25

PMid:19545412; PMCid:PMC2712449

Government of Western Australia., 2003. KEMH - King Edward Memorial Hospital and antenatal shared care guidelines for general practitioners. 5th ed. Subiaco: Government of Western Australia, pp. 3-23.

Guilliland, K., Tracy, S.K. \& Thorogood, J., 2006. Australian and New Zealand health and maternity services. In: Pairman, S., Pincombe, J., Thorogood, C. \& Tracy, S. eds. Midwifery: preparation for practice. Sydney: Churchill Livingstone Elsevier, pp. 3 - 33 .

Hadjigeorgiou, E., Kouta, C., Papastavrou, E., Papadopoulos, I. \& Mårtensson, L.B., 2012. Women's perceptions of their right to choose the place of childbirth: an integrative review. Midwifery, 28(3), pp. 380-390.

http://dx.doi.org/10.1016/j.midw.2011.05.006

PMid:21683487

Hatem, M., Sandall, J., Devane, D., Soltani, H. \& Gates, S., 2008. Midwife-led versus other models of care for childbearing women. Cochrane Database of Systematic Reviews 8(4), p. CD004667. http://dx.doi.org/10.1002/14651858.CD004667.pub2 PMid:18843666

Inhorn, M.C., 2006. Defining women's health: a dozen messages from more than 150 ethnographies. Medical Anthropology Quarterly, 20(3), pp. 345-378.

http://dx.doi.org/10.1525/maq.2006.20.3.345

PMid:16937621

International Confederation of Midwives., 2008a. The midwife is the first choice health professional for childbearing women. Available at: http://www.internationalmidwives.org/assets/uploads/documents/ Position\%20Statements\%20-\%20English/Reviewed\%20PS\%20 in\%202014/PS2008 019\%20V2014\%20The\%20Midwife\%20is\%20 the\%20First\%20Choice\%20ENG.pdf [2. 7. 2014]. 
International Confederation of Midwives, 2008b. Keeping birth normal. Available at: http://www.internationalmidwives.org/assets/ uploads/documents/Position\%20Statements\%20-\%20English/ Reviewed\%20PS\%20in\%202014/PS2008 007\%20V2014\%20 Keeping\%20Birth\%20Normal\%20ENG.pdf [2. 7. 2014].

Janssen, P.A., Ryan, E., Etches, DJ., Klein, M.C. \& Reime, B., 2007. Outcomes of planned birth attended by midwives compared with physicians in British Columbia. Birth, 34(2), pp. 140-147. http://dx.doi.org/10.1111/j.1523-536X.2007.00160.x PMid:17542818

Johanson, R., Newburn, N. \& MacFarlane, A., 2002. Has the medicalization of the childbirth gone too far? British Medical Journal, 324, pp. 892-895.

http://dx.doi.org/10.1136/bmj.324.7342.892

PMid:11950741; PMCid:PMC1122835

Johnson, M., Stewart, H., Langdon, R., Kelly, P. \& Yong, K.L., 2003. Women-centred care and caseload models of midwifery. Collegian, 10(1), pp. 30-34.

http://dx.doi.org/10.1016/S1322-7696(08)60618-6

Jomeen, J. \& Martin, C.R., 2008. The impact of choice of maternity care on psychological health outcomes for women during pregnancy and the postnatal period. Journal of Evaluation in Clinical Practice, 14(3), pp. 391-398.

http://dx.doi.org/10.1111/j.1365-2753.2007.00878.x

PMid:18373580

Kitzinger, S., 2011. Birth your way: choosing birth at home or in a birth center. California: DK Publishing, pp. 4-8.

Mann, C.J., 2003. Observational research methods. Research design II: cohort, cross sectional and case-control studies. Emergency Medicine Journal, 20, pp. 54-60.

http://dx.doi.org/10.1136/emj.20.1.54

McCourt, C., 2006. Supporting choice and control? Communication and interaction between midwives and women at the antenatal booking visit. Social Science and Medicine, 62(6), pp. 1307-1318.

http://dx.doi.org/10.1016/j.socscimed.2005.07.031

PMid:16126316

McLachlan, H.L., Forster, D.A.,Davey, M.A., Farrell, T., Gold, L., Biro, M.A., et al., 2012. Effects of continuity of care by a primary midwife (caseload midwifery) on caesarean section rates in women of low obstetric risk: the COSMOS randomised controlled trial. British Journal of Obstetrics and Gynaecology, 119(12), pp. 1483-1492.

http://dx.doi.org/10.1111/j.1471-0528.2012.03446.x

PMid:22830446
Metcalfe, A., Grabowska, K., Weller, C. \& Tough, S.C., 2013. Impact of prenatal care provider on the use of ancillary health services during pregnancy. BMC Pregnancy Childbirth, 11(13), pp. 62-69.

http://dx.doi.org/10.1186/1471-2393-13-62

PMid:23497179; PMCid:PMC3599935

National Institute for Health and Clinical Excellence, 2007. Intrapartum care - care of healthy women and their babies during childbirth.1st ed. London: NICE, pp. 14-33.

Odent, M.R., 2013. Synthetic oxytocin and breastfeeding: reasons for testing a hypothesis. Medicine Hypotheses, 81(5), pp. 889-891. http://dx.doi.org/10.1016/j.mehy.2013.07.044

Overgaard, C., Møller, A.M., Fenger-Grøn, M., Knudsen, L.B. \& Sandall, J., 2011. Freestanding midwifery unit versus obstetric unit: a matched cohort study of outcomes in low-risk women. BMJ Open, 1(2), p. e000262.

http.//dx.doi.org/10.1136/bmjopen-2011-000262

PMid:22021892; PMCid:PMC3191606

Page, L., 2007. Is there enough evidence to judge midwife led units safe? Yes. British Medical Journal, 335(7621), p. 642.

http://dx.doi.org/10.1136/bmj.39343.471227.AD

PMid:17901510; PMCid:PMC1995510

Parry, D.C., 2008. We wanted a birth experience, not a medical experience: exploring Canadian women's use of midwifery.

Health Care Women International, 29(8), pp. 784-806.

http://dx.doi.org/10.1080/07399330802269451

PMid:18726792

Pravilnik o sestavi, nalogah, pristojnostih in načinu dela komisije za medicinsko etiko, 1995. Uradni list Republike Slovenije št. 30.

Ryan, P., Revill, P., Devane, D. \& Normand, C., 2013. An assessment of the cost-effectiveness of midwife-led care in the United Kingdom. Midwifery, 29(4), pp. 368-376.

http://dx.doi.org/10.1016/j.midw.2012.02.005

PMid:22565064

Sutcliffe, K., Caird, J., Kavanagh, J., Rees, R., Oliver, K., Dickson, K., et al., 2012. Comparing midwife-led and doctorled maternity care: a systematic review of reviews. Journal of Advanced Nursing, 68 (11), pp. 2376-2386.

http://dx.doi.org/10.1111/j.1365-2648.2012.05998.x

PMid:22489571

Suzuki, S., Hiraizumi, Y., Satomi, M. \& Miyaha, H., 2011. Midwife-led care unit for 'low risk' pregnant women in a Japanese hospital. The Journal of Maternal-Fetal and Neonatal Medicine, 24(8), pp. 1046-1050.

http://dx.doi.org/10.3109/14767058.2010.545912

PMid:21231841 
Symon, A.G., Dugard, P., Butchart, M., Carr, V. \& Paul, J., 2011. Care and environment in midwife-led and obstetric-led units. A comparison of mothers' and birth partners' perceptions. Midwifery, 27(8), pp. 880-886.

http://dx.doi.org/10.1016/j.midw.2010.10.002

PMid:21251736

Zakon o zdravniški službi (uradno prečiščeno besedilo) (ZZdrSUPB3), 2006. Uradni list Republike Slovenije št. 72.

Wiegers, T.A., 2009. The quality of maternity care services as experienced by women in the Netherlands. BMC Pregnancy and Childbirth, 9, p. 18.

http://dx.doi.org/10.1186/1471-2393-9-18

PMid:19426525; PMCid:PMC2689853
Wiysonge, C.S., 2009. [Midwife-led versus other models of care for childbearing women]. The WHO Reproductive Health Library. Available at: http://apps.who.int/rhl/pregnancychildbirth/antenatalcare/general/cd004667/-Wiysongecs com/ en/ [8. 9. 2014].

World Medical Association, 2000. Declaration of Helsinki ethical principles for medical research involving human subjects. Available at: http://www.kme-nmec.si/Docu/HELSINKI2000.pdf [12. 12. 2013].

Yin, R.K., 2003. Applications of case study research. 2nd ed. Newbury Park, (CA): Sage Publications, pp. 55-60.

Cite as/Citirajte kot:

Prelec, A., Verdenik I. \& Poat, A., 2014. A comparison of frequency of medical interventions and birth outcomes between midwife led unit and obstetric unit in low-risk primiparous women. Obzornik zdravstvene nege, 48(3), pp. 166-176.

http://dx.doi.org/10.14528/snr.2014.48.3.16 